\title{
Demonstration of a multi-technique approach to assess glacial microbial populations in the field
}

\author{
MEGAN J. BARNETT, ${ }^{1} *$ MARK PAWLETT, ${ }^{2}$ JEMMA L. WADHAM, ${ }^{3}$ MIRIAM JACKSON, ${ }^{4}$ \\ DAVID C. CULLEN ${ }^{5}$ \\ ${ }^{1}$ British Geological Survey, Nicker Hill, Keyworth, Nottinghamshire, NG12 5GG, UK \\ ${ }^{2}$ School of Energy, Environment \& Agrifood, Cranfield University, Cranfield, Bedfordshire, MK43 OAL, UK \\ ${ }^{3}$ Bristol Glaciology Centre, School of Geographical Sciences, University of Bristol, Bristol, BS8 1SS, UK \\ ${ }^{4}$ Section for Glaciers, Ice and Snow, Hydrology Department, Norwegian Water Resources \& Energy Directorate, \\ P.O. Box 5091 Maj., N-0301 Oslo, Norway \\ ${ }^{5}$ Space Group, School of Aerospace, Transport \& Manufacturing, Cranfield University, Cranfield, Bedfordshire, \\ MK43 OAL, UK \\ Correspondence: Megan J. Barnett <m.barnett.s06@gmail.com>
}

\begin{abstract}
The ability to perform microbial detection and characterization in-field at extreme environments, rather than on returned samples, has the potential to improve the efficiency, relevance and quantity of data from field campaigns. To date, few examples of this approach have been reported. Therefore, we demonstrate that the approach is feasible in subglacial environments by deploying four techniques for microbial detection: real-time polymerase chain reaction; microscopic fluorescence cell counts, adenosine triphosphate bioluminescence assay and recombinant Factor $\mathrm{C}$ assay (to detect lipopolysaccharide). Each technique was applied to 12 subglacial ice samples, 12 meltwater samples and two snow samples from Engabreen, Northern Norway. Using this multi-technique approach, the detected biomarker levels were as expected, being highest in debris-rich subglacial ice, moderate in glacial meltwater and low in clean ice (debris-poor) and snow. Principal component analysis was applied to the resulting dataset and could be performed in-field to rapidly aid the allocation of resources for further sample analysis. We anticipate that in-field data collection will allow for multiple rounds of sampling, analysis, interpretation and refinement within a single field campaign, resulting in the collection of larger and more appropriate datasets, ultimately with more efficient science return.
\end{abstract}

KEYWORDS: ATP bioluminescence, Engabreen, fluorescence cell counts, in-field analysis, LPS endotoxin detection, real-time PCR, subglacial

\section{INTRODUCTION}

The discovery of active microbial communities at glacier beds (Sharp and others, 1999; Skidmore and others, 2000) led to an increased interest in the influence that microbial communities may have on the chemistry of glacial environments and biogeochemical cycling in aligned systems such as the oceans (Anesio and Laybourn-Parry, 2012; Wadham and others, 2013). Recent efforts have been devoted to characterize the microbial communities, estimating rates of metabolism and identifying potential metabolic pathways underneath different glaciers, and in different types of glacial environments (Christner and others, 2001; Skidmore and others, 2005; Stibal and others, 2012). Together, these studies have revealed distinct sub- and supra-glacial microbial communities that influence geochemical processes (Gaidos and others, 2004; Kaštovská and others, 2007), including carbon, nitrogen, sulphur and iron cycles (Christner and others, 2008; Hodson and others, 2008; Boyd and others, 2011). In turn, the local mineralogy influences the microbial population (Mitchell and others, 2013).

Various microbial-based analytical techniques have been employed to study glacial ice and related environments.

* This study was completed whilst the first author was affiliated with Cranfield University, UK.
These techniques are dominated by methods to visualize microbial cells and to detect cellular biomolecules including nucleic acids and lipids (Kaštovská and others, 2007; Mikucki and others, 2009; Barnett and others, 2012a; Zarsky and others, 2013; Stibal and others, 2015). The microbial activity of glacial ice has been studied (1) by measuring the uptake of labelled substrates such as acetate and amino acids (Foght and others, 2004; Sala and others, 2005; Hodson and others, 2007), (2) through inferences from imbalances in carbon and sulphur ions (Sharp and others, 1999; Wadham and others, 2004) and (3) by quantifying methane production (Stibal and others, 2012). Together, these techniques can be used to provide insights into the presence, abundance, diversity or activity of microorganisms. The general approach used in these studies has been to collect samples in the field and then transport them to, and analyse them in institutional laboratories. A few studies have transported equipment to the field and successfully analysed samples near the sampling site (Cowan and others, 2002; Hodson and others, 2007; Nadeau and others, 2008).

Ideally, in-field analysis could be used to detect and quantify a wide variety of biomolecules (nucleic acids, proteins and lipids), along with biologically relevant ions (e.g. phosphates, nitrates and organic acids) and gases (e.g. carbon dioxide, methane and hydrogen sulphide). The detection of 
each of these targets can be made by several instruments, generally including for example, a thermal cycler, nucleic acid sequencer, gas chromatograph, liquid chromatograph and mass spectrometer. If just a single target is required then a bespoke assay, or dedicated instrument may be available for example adenosine triphosphate (ATP) bioluminescence or oxygen microelectrode. To use a particular technique in the field, suitable technology needs to be available that is portable in terms of mass, volume and power requirements. Techniques already applied in the glacial field environment are summarized by Barnett and others (2012a). Sample processing also needs to be feasible infield. As with designing any study, the analytical techniques used need to be relevant and complimentary. If little is known about the field site then 'catch all' techniques, which are flexible regarding sample size and type, would be important. To aid the choice of in-field techniques the above points should be considered, along with the quality, quantity and type of data required and the time available in and out of the field.

Nucleic acid identification is a core technique for modern microbiology with real-time polymerase chain reaction (PCR) being a readily available implementation and an obvious choice. Primer pairs are designed to target a section of DNA, allowing the identification of sequences that represent microbial diversity (Segawa and others, 2005) or the presence of function pathways (Kandeler and others, 2006; Cameron and others, 2012). The popularity of real-time PCR means multiple commercially available systems are available and include MiniOpticon ${ }^{\text {TM }}$ (Bio-Rad Laboratories Ltd., UK), ABI Prism ${ }^{\circledR} 7700$ (Applied Biosystems Inc, USA) and LightCycler ${ }^{\circledR}$ (Roche Applied Science, Germany). Also, multiple manufacturers make DNA extraction kits suitable for soil samples and include Mo Bio Laboratories Inc., USA (PowerSoil ${ }^{\circledR}$, PowerMax ${ }^{\circledR}$ and Ultraclean $\left.{ }^{\circledR}\right)$, Norgen Biotek Corp., Canada, Cambio Ltd, UK (SoilMaster ${ }^{\mathrm{TM}}$ DNA Extraction Kit) and Omega BioTek Inc., USA (E.N.Z.A. ${ }^{\circledR}$ Soil DNA kit). Thus, little development of bespoke instrumentation or sample processing is required for in-field analysis.

Cell counts are frequently used as a microbiological enumeration technique. Their limited reliance on experimental design and popularity allow for more direct comparison between samples and with other glacial data (Foght and others, 2004; Zhang and others, 2008), and they are an obvious choice for in-field deployment. Fluorescentlystained cell counts are the current laboratory norm and can be performed manually with fluorescence microscope, or automatically with a flow cytometer. Although microscope cell counts are more labour intensive, minimal method development is required for analysis, unlike flow cytometry where development is required to distinguish between fluorescence cells and other particles. Microscope fluorescent cell counts have been difficult to implement in-field as traditional fluorescent microscopes are not readily portable. A recent development, driven by the desire to implement fluorescent microscope-based diagnosis of tropical diseases in developing countries, has resulted in the availability of field portable, battery powered fluorescence microscopes (CyScope, Partec UK, Canterbury, UK).

ATP is found in every living cell and thus its abundance is widely used as a proxy for extant life (Fairbanks and other, 1984). ATP can be detected using a one-step assay using the bioluminescent pathway of fireflies to produce light in proportion to ATP concentration. This ATP bioluminescence assay has previously been used successfully in Antarctic Dry Valleys to detect biomass (Cowan and others, 2002). Demand from the food industry, for on-site cleanliness testing, has led to the production of several commercially available, portable systems $\left(\mathrm{HyLiTE}^{\circledR} 2\right.$ Hygiene Monitoring System, Merck KGaA, Germany and LIGHTENING MPV ${ }^{\circledR}$ BioControl Systems Inc., USA).

The Limulus amebocyte lysate ( $\mathrm{LAL}$ ) assay is used in the pharmaceutical industry to test for endotoxins or lipopolyscaharride (LPS) and is required for drug quality control during manufacture. LPS is a major component of the cell wall of Gram-negative bacteria and thus the LAL assay has been used to quantify Gram-negative bacteria, including in ice samples (Karl and others, 1999; La Ferla and others, 2004). Isolation of the LPS sensitive cofactor, Factor C, has led to the production of recombinant Factor $\mathrm{C}(\mathrm{rFC})$ assay, which is more suited to field deployment (Ding and Ho, 2001). This is due to a simplification of the protocol, leading to a one step assay with a fluorescence end-point that can be detected in a handheld fluorimeter.

It is hypothesized that a number of significant advantages could be gained if microbial detection techniques could be employed in-field rather than in institutional laboratories. Logistical costs associated with sample storage and transport will be reduced, as well as the delay between sample collection and analysis (Barnett and others, 2012a). Delays prior to sample analysis could allow the microbial population structure to alter, creating uncertainties in interpretation. Thus, our aim is to demonstrate the first in-field deployment of multiple, microbialbased analytical techniques within an icy environment: realtime PCR, fluorescence cell counts, ATP bioluminescence and rFC assay. All four techniques were conducted in the field to analyse subglacial ice, subglacial meltwater and snow samples from Engabreen (the Enga Glacier) in Northern Norway.

\section{MATERIALS AND METHODS}

\subsection{Field site}

All samples were from Engabreen, an outlet glacier of the Svartisen Ice Cap that straddles the Arctic Circle in the Norwegian Arctic (glacier snout at $66^{\circ} 41^{\prime} \mathrm{N}, 13^{\circ} 46^{\prime} \mathrm{E}$ ). A unique aspect of Engabreen is the Svartisen Subglacial Laboratory, which is a facility run by the Norwegian Water and Energy Resources Directorate providing access to pristine subglacial samples. The laboratory is a basic, heated wooden cabin within and accessed via tunnels drilled into the bedrock underneath and around the glacier. Pristine ice samples were accessed through a research shaft from the bedrock tunnels to the glacier bed. An ice cave was excavated in the base of the glacier by hot water drilling. Other sampling sites were meltwater streams from bedrock tunnels that were not exposed to the external environment (subglacial water and mixed water) and snow samples external to the bedrock tunnel system.

\subsection{Sample collection and processing}

The samples were collected in and around Engabreen from 19 to 27 November 2008 and 18-27 March 2009.

There have been no formal studies performed of the hydrogeology at Svartisen. However, observation of the bedrock and of the surface hydrology as well as the 
hydrology in the subglacial tunnel system tells us several things. (1) The water flow through the bedrock is assumed to be independent of the season, due to the thickness of the rock above the tunnel system. Comparing seasonal discharge shows that the winter discharge, from 1 November to 30 April for the 8 years between 2006 and 2013 inclusive, is $3.6 \%$ in an area with mixed subglacial melt and subaerial source (i.e. snow melt and precipitation) and $4.8 \%$ in an area with subaerial source (Fonndalstunnel), compared with the summer discharge, from 1 May to 31 October. (2) As this is a maritime region with a mild climate, there is subglacial melt, snowmelt and rain even in the winter months. The actual hydrogeological contribution will thus be much smaller than these percentages. (3) The source of the hydrologeological water is thought to be local due to the topography in the area, and is thus derived from local snowmelt and percolation of precipitation.

A total of 5 sample types were analysed: debris-rich ice, clean ice, subglacial water, mixed water and snow. Both ice sample types were collected from the ice cave, where a visible boundary separated the two. The subglacial water samples were collected from a tunnel (Spiral Tunnel) with multiple subglacial intakes, giving the water a predominantly (sub) glacial origin, and a small amount of groundwater. The mixed water samples were collected from the same point over different days, and at the confluence of two watercourses: the Spiral Tunnel and Fonndalstunnel (containing water with mainly meteoric origin, and small amounts of (sub) glacial water and groundwater). A total of 32 samples were collected, including duplicates of the six debris-rich ice samples. All 32 samples were analysed by real-time PCR and ATP bioluminescence. For the fluorescence cell counts and rFC assay only one duplicate from the debrisrich ice was analyzed. Three further samples (mixed water) were not assayed for rFC assay due to sample loss.

All water samples were collected in autoclaved $250 \mathrm{~mL}$ Beckman bottles (Beckman, USA), or in sterile $1.5 \mathrm{~mL}$ Eppendorf tubes and returned to the field-laboratory for processing and analysis. As a proof of concept, subglacial water samples from 2009 were filtered at the sample site, and the filter membrane was returned to the field-laboratory for further processing and analysis. All bottles were rinsed at least three times with sample water before being filled. Snow samples were placed into sterile sample bags using gloves wiped in $96 \%$ ethanol. The basal ice samples were extracted from the ice cave in the research shaft. In 2008, an ethanol wiped ice axe and chisel were used. In 2009 the samples were extracted using a chainsaw. The ice was then wrapped in foil (previously held at $250^{\circ} \mathrm{C}$ for $4 \mathrm{~h}$ to remove LPS) within the ice cave and moved to the field-laboratory. The surface of the chainsaw collected samples was washed with ethanol and then with autoclaved water to remove surface contaminants. Ice and snow samples were melted at ambient in-field laboratory temperature $\left(\sim+18^{\circ} \mathrm{C}\right)$ in sterile sample or autoclave bags and then, if necessary, moved to $+3^{\circ} \mathrm{C}$ storage prior to processing.

For ATP and PCR analyses, between $10 \mathrm{~mL}$ (debris-rich ice) and $3000 \mathrm{~mL}$ (clean ice) of sample was filtered onto $0.22 \mu \mathrm{m}$ pore size filter membranes; this is the standard pore size used to filter microorganisms. The membranes were then split in two; one half was processed for ATP bioluminescence and the other half for real-time PCR. For fluorescence cell counts, between $1 \mathrm{~mL}$ (debris-rich ice) and 50 $\mathrm{mL}$ (all water sources) of each sample were preserved to a final concentration of $2 \%$ glutaraldehyde. For LPS quantification, $1 \mathrm{~mL}$ of each sample was aliquoted for later analysis.

\subsection{Storage and timing of analyses}

All ATP and LPS measurements and DNA extractions were conducted in the field laboratory.

The in-field fluorescence microscope was not available for the November 2008 field campaign, therefore the samples were preserved for cell counts, returned from the field (between +2 and $+8^{\circ} \mathrm{C}$ ) and analyzed in institutional laboratories. The DNA extracts for November 2008 were also returned for analysis as the real-time PCR instrument failed upon start up. After consultation with the manufacturer, it was later diagnosed as a power supply problem that was likely to have been caused by moisture accumulation inside the machine; this problem had not previously been encountered. The majority of fluorescence cell counts and real-time PCR analyses were conducted in the field (March 2009), however due to time constraints the following samples were processed in the field, and were transported to institutional laboratories where the samples were analyzed. Fluorescence cell counts, mixed water, debris-rich ice and clean ice were all analyzed in institutional laboratories. For real-time PCR analysis all primers for mixed water samples and eubacteria and methane consumption (mxaF) primers for debris-rich ice and clean ice were analyzed in institutional laboratories.

All samples (with the exception of mixed water in March 2009) were assayed, preserved or extracted with $24 \mathrm{~h}$ of collection or upon completion of melting. The mixed water samples were collected and processed daily (as previously described) and analyzed together at the end of the field campaign. All mixed water samples were stored, prior to analysis, either at $-15^{\circ} \mathrm{C}$ for ATP bioluminescence, rFC assay and real-time $\mathrm{PCR}$ or at $+3^{\circ} \mathrm{C}$ for fluorescence cell counts.

\subsection{Supporting equipment}

In addition to the analytical equipment required for each technique (Table 1), general laboratory equipment and consumables were needed to be transported to the field to store, transport and process samples. The ability to sterilize water and consumables was also required. Water was filtered through a $0.22 \mu \mathrm{m}$ filter membrane and then sterilized in a stove top pressure cooker held for a minimum of $30 \mathrm{~min}$ (at $115^{\circ} \mathrm{C}$ ). All consumables were sterilized in the stove top pressure cooker held at operating pressure for a minimum of 15 $\min$.

\subsection{Real-time PCR}

DNA was extracted directly from disaggregated filter membranes using UltraClean ${ }^{\mathrm{TM}}$ DNA Isolation Kit (CamBio Ltd, UK product code UC-12800 Mo Bio Laboratories Inc.). The manufacturer's protocol was followed as closely as possible, two exceptions being that all centrifuge steps were performed at $7200 \times \mathbf{g}$ instead of $10000 \times \mathbf{g}$ and samples were shaken manually instead of using a vortex mixer. Extraction blanks, consisting of a moistened filter membrane, were conducted with each extraction batch (three in March 2008 and two in November 2009). These extraction blanks were used as negative controls in all PCR runs. 
Table 1. Major equipment transported to Engabreen

\begin{tabular}{|c|c|c|c|c|}
\hline \multirow[t]{2}{*}{ Technique } & Instrument & Mass & \multirow[t]{2}{*}{ Voltage requirements } & $\begin{array}{l}\text { Approximate labour time to } \\
\text { process ten samples }\end{array}$ \\
\hline & & $\mathrm{kg}$ & & $\min$ \\
\hline \multirow[t]{2}{*}{ Real-time PCR } & Bio-Rad MiniOpticon ${ }^{\mathrm{TM}}$ & 6.8 & 100-240 VAC & \multirow[t]{2}{*}{50} \\
\hline & Micro-Centrifuge & 2.5 & $120 \mathrm{~V}$ & \\
\hline Cell counts & Partec CyScope ${ }^{\circledR}$ & 2.7 & $\begin{array}{l}\text { 100-240 VAC and/or rechargeable } \\
\text { battery pack }\end{array}$ & 120 \\
\hline ATP bioluminescence & Merck Hy-LiTE ${ }^{\circledR} 2$ & 1.26 & $4 \times 1.5 \mathrm{~V}$ (AA batteries) & $30+15^{*}$ \\
\hline LPS & Turner BioSystems PicoFluor ${ }^{\mathrm{TM}}$ & 0.4 & $4 \times 1.5 \mathrm{~V}$ (AAA batteries) & $10+2+2+2+2+2+$ \\
\hline
\end{tabular}

* One session of 30 min followed by a further 15 min after 1 hour.

+One session of $10 \mathrm{~min}$ followed by five sets of 2 min every $0.5 \mathrm{~h}$.

The choice of functional pathway targets was driven by previous studies: sulphate reduction (dsrA) in ice cover of lakes in McMurdo Dry Valleys, Antarctica (Karr and others, 2005); denitrification (nirK) in alpine glacier foreland samples (Kandeler and others, 2006); methanotrophy (pmoA) in polar soils (Pacheco-Oliver and others, 2002); mxaF in Arctic soils (Wartiainen and others, 2003); and nitrogen fixation (nifH) in lakes in McMurdo Dry Valleys, Antarctica (Olson and others, 1998).

Real-time PCR was conducted using a CFX96 real-time PCR instrument for the samples from November 2008 and a MiniOpticon ${ }^{\mathrm{TM}}$ Monitor real-time PCR instrument in March 2009 (both instruments from Bio-Rad Laboratories Ltd.). The total PCR reaction volume was $10 \mu \mathrm{L}$ and included $1 \mu \mathrm{L}$ of DNA extract, $500 \mathrm{nM}$ of forward and reverse primer and iQ SYBR green supermix (Bio-Rad Laboratories Ltd.). The realtime PCR conditions used in both instruments were $3 \mathrm{~min}$ at $95^{\circ} \mathrm{C}$ then 40 cycles of denaturing at $95^{\circ} \mathrm{C}$, annealing at temperatures stated in Table 2 and extension at $72^{\circ} \mathrm{C}$, each for $30 \mathrm{~s}$. Two primer pairs target bacteria, however to distinguish between them they are referred to as bacteria and eubacteria (nomenclature from original papers, Table 2). PCR amplification was followed by a melt curve, where the samples were held for $1 \mathrm{~s}$ every $1^{\circ} \mathrm{C}$ between 65 and $95^{\circ} \mathrm{C}$. The position of threshold lines and corresponding cycle threshold (Ct) values were acquired using CFX Manager ${ }^{\mathrm{TM}}$ Software $v 1.0$ (Bio-Rad Laboratories Ltd.). A threshold line was set for each PCR run, when the sample signal crossed this threshold, the number of amplification cycles required was recorded as the $\mathrm{Ct}$ value, and this was used for further data analysis.

\subsection{Cell counts}

Glutaraldehyde preserved samples were filtered onto $0.2 \mu \mathrm{m}$ pore size filter membrane (Millipore, FDR-312-020W, Fisher Scientific). The filter membranes were then stained with $400 \times$ dilution of SYBR ${ }^{\circledR}$ gold (Invitrogen Ltd., UK) for 15 min in the dark. Cells were then counted manually using a CyScope ${ }^{\circledR}$ field portable fluorescence microscope (Partec UK, UK) with RB $455 \mathrm{~nm}$ excitation filter and $520 \mathrm{~nm}$ emission filter. Duplicate slides were prepared per sample and between 20 and 50 fields of view were counted per slide.

\subsection{ATP extraction and determination}

ATP Bioluminescence Assay Kit HSII (Roche Diagnostics Ltd, UK) was used in accordance with the manufacturer's protocol to extract and analyse samples. $1 \mathrm{~mL}$ of boiling 100 $\mathrm{mM}$ Tris, $4 \mathrm{mM}$ ethylene diamine tetraacetic acid (EDTA) buffer was added to the disaggregated filter membrane. Samples were then incubated in a boiling water bath for 2 min. Once cool $\left(\mathrm{at}+3^{\circ} \mathrm{C}\right)$, samples were shaken and $50 \mu \mathrm{L}$ of sample was added to $50 \mu \mathrm{L}$ of ATP bioluminescence reagents. Sample luminescence was quantified by comparison with a standard curve $\left(10^{-8}-10^{-11} \mathrm{M}\right.$ ATP) using a HYLiTE $^{\circledR} 2$ luminometer (Merck, VWR International Ltd., Lutterworth, UK). After analysis, samples were autoclaved and $100 \mu \mathrm{L}$ of $10^{-8} \mathrm{M}$ ATP spike was added to all samples and the blank to correct for interference from the sediment in sample (Barnett, 2010). The bioluminescence value of this spike was compared with the bioluminescence value of the blank to calculate spike recovery.

\subsection{LPS determination}

The Cambrex PyroGene ${ }^{\circledR}$ rFC endotoxin detection system (product code 50-658U, Lonza, UK) was used to quantify LPS concentration. Due to the non-temperature controlled conditions in which the assay was conducted, the manufacturer's protocol was modified (Barnett and others, 2012b). Briefly, $50 \mu \mathrm{L}$ of sample was added to $50 \mu \mathrm{L}$ of working reagent (made up as per manufacturer's protocol). Fluorescence measurements (PicoFluor handheld fluorometer, Turner BioSystems, CA, USA), were made after the addition of sample (0 hours) then every 0.5 hours for $3 \mathrm{~h}$. Fluorescence was quantified using endotoxin unit (EU) standards between 0.1 and $10 \mathrm{EU} \mathrm{mL}^{-1}$. From these data, the assay response (relative fluorescence units $\mathrm{min}^{-1}$ ), for each sample and standard, was calculated by fitting linear least squares fit of fluorescence values to time, and was used in subsequent data interpretation. Assay response values were used when the $r^{2}$ values were $>0.95$.

\subsection{Statistical analysis}

The collection of a large multi-technique dataset provides a challenge for simple interpretation, especially in time limited field campaigns. Therefore, we employed the multivariate statistical analysis technique of principal component analysis (PCA), to explore the potential of such approaches to aid rapid in-field dataset interpretation. PCA converts a dataset with multiple, possibly dependent, variables into uncorrelated principal components (PC). Each PC is numbered such that PC1 explains most of the variation, PC2 the second most variation etc. The correlation or loading value, of each variable (eigenvector) to a PC can also be informative. If a variable is separate from a centralized cluster of variables it may be considered to have a larger influence 
Table 2. Genes targeted with real-time PCR and the annealing temperatures.

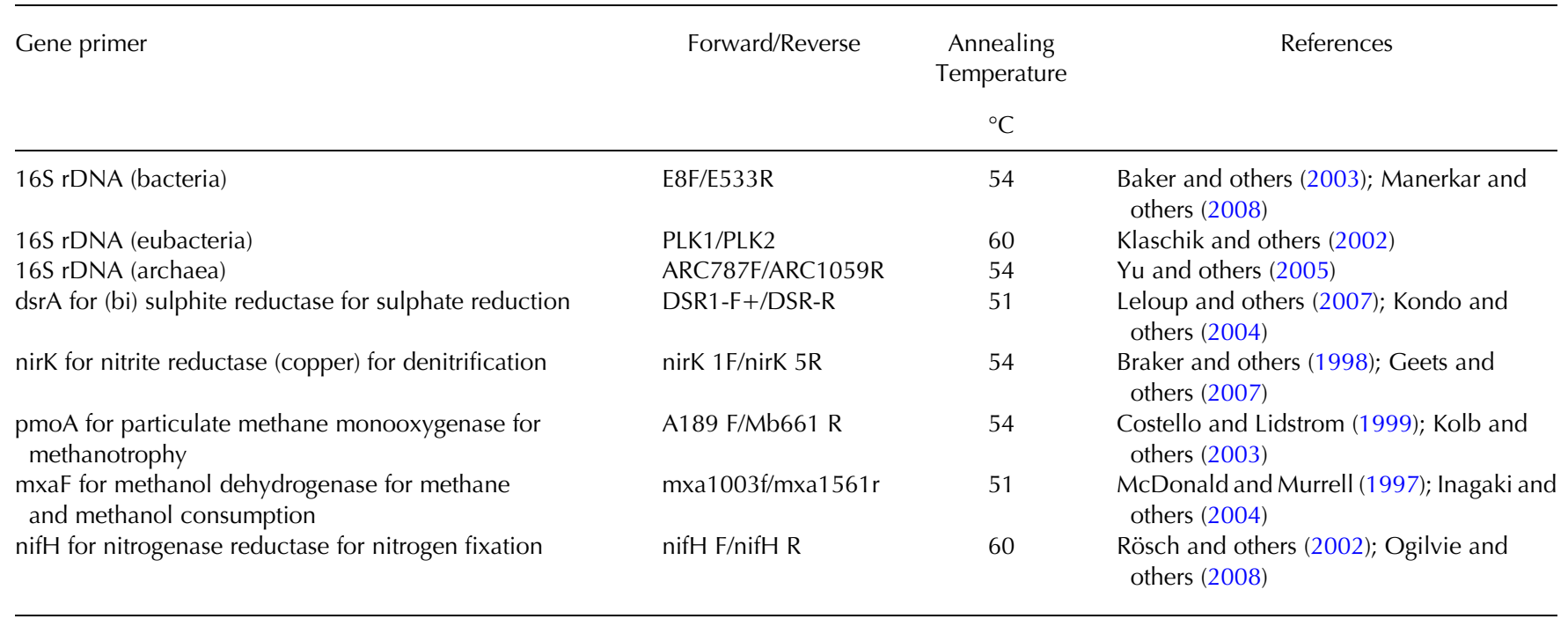

on the variation in the data. Analysis of variance was completed on the PCA factor scores to test significance.

The ATP, LPS and cell count data were $\log _{2}$ transformed to achieve a normal distribution. To analyze the real-time PCR, cycle threshold $(\mathrm{Ct})$ values were corrected for volume filtered and, as lower Ct values represent higher DNA concentration in the sample, the negative of the corrected Ct value was used. Outliers were identified and removed from the realtime PCR data by visual inspection of melting curves and by p-plot of residuals data. Missing data for ATP, cell counts and real-time PCR in some samples were substituted by the nearest equivalent sample, giving an interpolated dataset (Tabachnick and Fidell, 2007). Conducting PCA of the original dataset and the interpolated data gave similar relative results in terms of sample positions on the $\mathrm{PC} 1 \times$ PC2 factor plane (data not shown), and therefore using an interpolated dataset was not considered a significant source of bias when analyzing the samples. All statistical analyses were conducted using Statistica 9.0 (StatSoft Inc. USA, 2009).

\section{RESULTS}

Real-time PCR (semi-quantitative) results are presented in Tables 3 and 4, cell counts, ATP bioluminescence and rFC assay (quantitative) results are in Table 5 .

All the sample types gave a positive detection signal with the real-time PCR primer pairs for bacteria, eubacteria, archaea, dsrA and mxaF. However, no nirk was detected in the clean ice samples, no nifH was detected in the snow samples and no mxaF was detected in the mixed water samples (Table 4).

The results in Tables 3 and 4 show that the highest concentrations of DNA were found in debris-rich ice, with clean ice and snow samples having the lowest. The DNA target sequences were highest for the bacterial and eubacterial primers, and the most abundant functional target sequence was pmoA in all sample types except for debrisrich ice where it was nifH. Even excluding the sample types where no target sequence was detected, the lowest concentration of functional pathway targets was not consistent, with drsA, nirK, mxaF and nifH all being the lowest in at least one sample type.

All samples analyzed by cell counts were greater than the limit of detection (Table 5). ATP could be detected in each of the sample types assayed, however ATP was quantifiable in only three of 12 of the debris-rich ice samples. LPS could not be detected in any of the debris-rich ice, clean ice or snow samples using the rFC assay (Table 5).

Overall, the results in Tables 3-5 show that there were significantly higher concentrations of biomarkers in the debris-rich ice compared with the glacial ice, with up to three-orders of magnitude more using cell counts $(p<$ 0.001 for cell counts). The concentrations of biomarkers in the water samples were generally intermediate to these extremes. The spread of data for the water source samples was narrower when compared with both types of ice sample and was generally less than an order of magnitude.

\subsection{Multivariate analysis}

PCA was applied to the multi-technique dataset (Fig. 1). The rFC assay data were not included in the PCA analysis as it was incomplete and highly biased (only one LPS measurement in the 12 ice samples).

PCA of the multi-technique dataset demonstrated that PC1 and PC2 accounted for $87 \%$ of the total variation, with PC1 accounting for $79 \%$, and PC2 8\% (Fig. 1a). The degree of clustering associated with the sample types was variable, with the mixed water samples being the most tightly clustered on the PC1 $\times$ PC2 factor plane, and the debris-rich ice samples exhibiting the greatest variability in PC1 and PC2 (Fig. 1a).

On PC1, debris-rich ice was significantly $(p<0.001)$ that glacial ice, snow and mixed water samples, but there was no significant $(p>0.05)$ difference between debris-rich ice and the subglacial water. In addition (PC1) the clean ice samples were significantly $(p<0.01)$ different than subglacial water. Additional separation of the sample types occurred on PC2, with the debris-rich ice being separated from the subglacial water samples $(p<0.05)$.

Figure 1b demonstrates that: (1) all biomarkers provide a positive contribution $(>0.85)$ to the PCA loads, with the bacterial real-time PCR primer data contributing the most to the overall variance, and to PC1 and that ATP bioluminescence data contributed the most to PC2 and (2) that the PCR primers cluster into three groups on the PCA plot: archaea; dsrA, $\mathrm{mxaF}$ and bacteria; and nirK, pmoA, nifH and eubacteria. 
Table 3. Real-time PCR results for the $16 \mathrm{~S}$ genes with the different sample types

\begin{tabular}{|c|c|c|c|c|c|c|}
\hline & \multicolumn{2}{|c|}{ Bacteria } & \multicolumn{2}{|c|}{ Eubacteria } & \multicolumn{2}{|c|}{ Archaea } \\
\hline & $\begin{array}{c}\text { Greater } \\
\text { than LoD* }\end{array}$ & $\begin{array}{l}\text { Range of sample } \\
\text { means }(\Delta \mathrm{Ct})\end{array}$ & $\begin{array}{l}\text { Greater } \\
\text { than LoD* }\end{array}$ & $\begin{array}{l}\text { Range of sample } \\
\text { means }(\Delta \mathrm{Ct})\end{array}$ & $\begin{array}{l}\text { Greater } \\
\text { than LoD* }\end{array}$ & $\begin{array}{c}\text { Range of sample } \\
\text { means }(\Delta \mathrm{Ct})\end{array}$ \\
\hline Debris-rich ice & 7 of 12 & $8.2-14.4$ & 10 of 12 & $9.0-17.3$ & 9 of 12 & $10.5-16.9$ \\
\hline Clean ice & 3 of 6 & $4.7-8.0$ & 2 of 6 & $2.9-8.1$ & 5 of 6 & $5.2-12.3$ \\
\hline Subglacial water & 6 of 6 & $7.6-12.0$ & 6 of 6 & $7.2-10.9$ & 6 of 6 & $11.6-18.0$ \\
\hline Mixed water & 6 of 6 & $5.9-8.9$ & 6 of 6 & $6.8-9.6$ & 6 of 6 & $9.3-13.5$ \\
\hline Snow & 1 of 2 & 5.9 & 0 of 2 & & 2 of 2 & $6.3-6.5$ \\
\hline Total & \multicolumn{2}{|c|}{23 of $32>\operatorname{LoD}$} & \multicolumn{2}{|c|}{24 of $32>\operatorname{LoD}$} & \multicolumn{2}{|c|}{28 of $32>$ LoD } \\
\hline
\end{tabular}

Samples greater than LoD have mean Ct values at least 3.16 ( $\log _{2} 10$ for a tenfold difference) units away from the mean Ct for the extraction blank, amplification also occurred within 40 cycles and had appropriate melt curves (assessed visually). The $\Delta \mathrm{Ct}$ values are relative to the extraction blank and sample volume, and are the difference between the mean $\mathrm{Ct}$ value for the sample and the mean Ct value for the extraction blank. The $\Delta \mathrm{Ct}$ values are also corrected for differences in sample volume, making them equivalent to what would be expected if $1 \mathrm{~L}$ of sample was concentrated and extracted.

* LoD - limit of detection.

\section{DISCUSSION}

Each of the four techniques used could be successfully applied to samples from Engabreen and surrounding area (Tables 3-5). However for certain sample types, namely debris-rich ice, clean ice and snow, at least half the samples were indistinguishable from the blank. This was true for one or more of the techniques. The low cell counts in clean ice and snow samples indicate that the target biomarker concentration could be below the lowest limit of detection of the appropriate assay, hence increasing target concentration during sample processing could address this. However, the debris-rich ice samples had the highest cell counts, therefore the ATP and LPS concentrations were unlikely to be below the detection limit of their assays. Due to the large surface area of the sediment in the debris-rich ice, ATP could have been absorbed onto the sediment surface, which has been previously observed with clay minerals (Jenkinson and Oades, 1979). This is supported by not being able to detect a $10^{-8} \mathrm{M}$ ATP spike. LPS has also been shown to be absorbed by clay minerals (Schaumberger and others, 2014).

\subsection{Choice and implementation of techniques}

Of the techniques used here, the most powerful is real-time $P C R$, as it is capable of measuring microbial presence, abundance, diversity and activity (through reverse transcriptase PCR to detect RNA). However the instrumentation also had the greatest mass and power requirements (Table 1). As sample processing for PCR analysis required only basic modifications to established approaches for field deployment, it could be taken into the field with minimal lead time. Realtime PCR was complemented by additional techniques, in particular fluorescence cell counts, as this allowed direct comparison between this study and others. However, fluorescence cell counts was the most time intensive technique (Table 1), making it impractical to analyse a large number of samples in a short field campaign. Significant improvements in time efficiency for fluorescence cell counts could be introduced by use of portable flow cytometry system. Flow cytometry lends itself to aqueous based samples and success has been reported in glacial surface samples (Irvine-Fynn and Edwards, 2014). However, Stibal and others (2015) compared the recovery and reproducibility of cell counts, quantitative PCR (qPCR) and flow cytometry as methods to measure cell concentrations and found interference from particles in simulated glacial samples reduced the reliability of flow cytometry and quantitative PCR (qPCR) data. Stibal and others (2015) argue that qPCR is more suited to providing data on community structure; this is supported by the real-time PCR results obtained in this study. Flow cytometry could be applicable for repeat trips to the same field site as knowledge of expected cell concentrations and types of sediments could be used to develop methods to reliably distinguish cells and cell-like particles.

ATP bioluminescence provides an alternative and quicker estimate of biomass, compared with cell counts (Cowan and others, 2002; Aycicek and others, 2006). During this field campaign, ATP bioluminescence was successful with all sample types, however improvements in sample processing would be beneficial for samples similar to debris-rich ice; ATP could only be detected on 3 of 12 samples because of sample matrix interference. The rFC assay was quick and simple to conduct (Table 1), however the inability to detect LPS in several sample types limits the use of the rFC assay without the development of further sample processing. In addition to the factors that were considered prior to the field campaigns in the selection of techniques for the field (information relevance, complementarity, technology and sample processing), time taken to complete the technique and sample preparation needs to be considered. All instruments used here, except the real-time PCR thermal cycler, required manual input for each data point. The time factor is emphasized during short field campaigns, such as to Engabreen, as although each technique was completed in the field, time restrictions meant that not all the analyses could be completed on all the samples in-field.

Due to the failure of the real-time PCR thermal cycler in the 2007 field campaign, the replacement thermal cycler and portable microscope (instruments not previously used in Engabreen) were put through simulated transport, storage and operation conditions. This included transporting to LowTex facilities (Bristol University, UK), where the instruments were stored for several days at $4^{\circ} \mathrm{C}$. After $24 \mathrm{~h}$, to equilibrate temperature and moisture, both instruments were also operated at $4{ }^{\circ} \mathrm{C}$. No problems were encountered with either instrument. During the 2008 field campaign the thermal cycler was given $24 \mathrm{~h}$ to equilibrate temperature and moisture before operation.

To allow for reduced mass and power requirements, field portable instruments tend to be less flexible, less precise and/ 


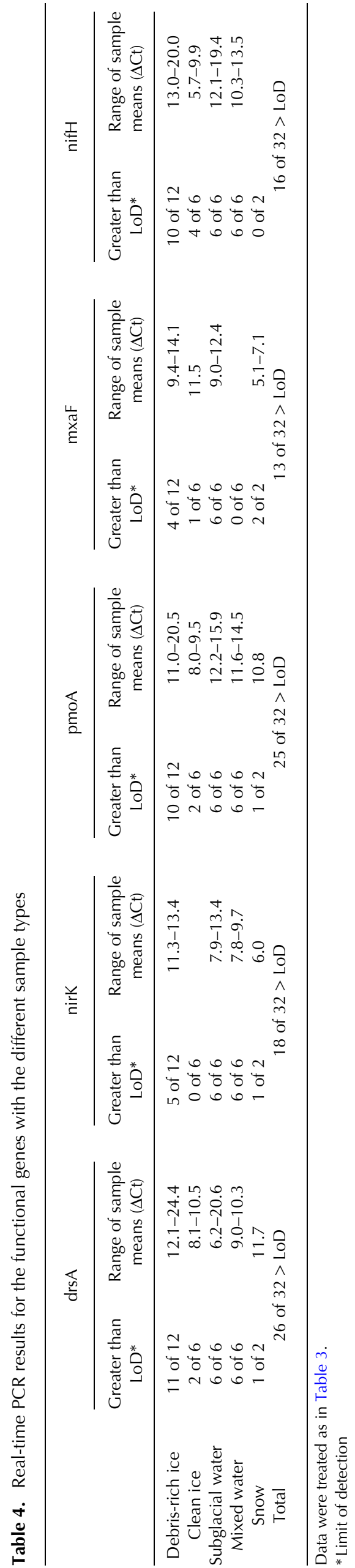

or require greater manual input than equivalent non-moveable instruments. The reduction in flexibility was not a significant issue for this study, as instruments were chosen for assays of interest. Reduced precision may be an important consideration if the detection of small differences among samples is desired. Greater manual input may increase the chance of human induced inaccuracies. Along with time pressures, already discussed, the final major compromise when conducting analysis outside of an institutional laboratory is reduced standard contamination controls. Sterilization measures such as wet heat (pressure cooker), dry heat (flaming) and wiping surfaces with ethanol, were used regularly during collection and analysis of samples. However, non-zero values were seen in extraction blanks or negative controls for ATP bioluminescence, rFC assay and real-time PCR data (data not shown). Thus, LoD was set at triple the blank value for ATP and LPS and tenfold the blank value for real-time PCR. Lower LoD could be achieved with these assays by improving contamination controls. The dedicated laboratory within Engabreen did not contain facilities to create a sterile atmosphere as would be provided by a laminar flow cabinet or the shadow of a Bunsen burner. To further reduce the potential for contamination in a field laboratory, portable glovebags could be used (Purair $^{\mathrm{TM}}$ FLEX, Air Science, USA).

\subsection{Relevance and interpretation of resultant dataset}

The data shown in Tables 3-5 agree with general distribution of microorganisms from published data, where microbial biomarkers and hence assumed microorganisms are higher in the debris-rich ice compared with the clean ice (Foght and others, 2004; Mader and others, 2006). Foght and others (2004) found fluorescence cell counts of $2.3 \times 10^{6}( \pm 0.1)$ cells g $^{-1}$ sediment in recently exposed, glacially abraded bedrock and viable cell counts were typically 3-4 orders of magnitude higher in these sediments than glacial ice, which is consistent with the difference we found here of $3 \times 10^{4}$ to $1 \times 10^{6}$ cells $\mathrm{mL}^{-1}$ in debrisrich ice and $2 \times 10^{2}$ to $1 \times 10^{3}$ cells $\mathrm{mL}^{-1}$ in clean ice. The general trend, seen in the cell count data, is reflected in the other techniques.

Previous studies of the diversity of microorganisms in glacial ice and meltwaters show a dominance of bacterial over archaeal species (Sjöling and Cowan, 2003; Simon and others, 2009), which is reflected in the $16 \mathrm{~S}$ real-time PCR results from Engabreen and the surrounding environment (Table 3). As the choice of functional pathway primers was based on previous studies in icy environments, it was expected that they would be present in Engabreen (Tables 3,4). The presence of all functional pathways in some, if not all, sample types throughout the Engabreen system, suggests a diverse range of potential microbial functions. The similarity of the in-field generated dataset to literature reports from similar environments, although via institutional analyses, supports the interpretation that the infield analysis reported here is broadly consistent with the established approaches.

\subsection{PCA}

If multiple cycles of sampling and measurements are being made, or early samples are used for intelligence led sampling, the dataset that emerges out of the use of multiple techniques needs to be rapidly interpreted in-field. For such 
Table 5. The results for the quantifiable biomarkers

\begin{tabular}{|c|c|c|c|c|c|c|}
\hline & \multicolumn{2}{|c|}{ Cell counts } & \multicolumn{2}{|c|}{ ATP bioluminescence } & \multicolumn{2}{|c|}{ rFC assay } \\
\hline & $\begin{array}{c}\text { Greater than } \\
\text { LoD* }\end{array}$ & $\begin{array}{l}\text { Range of sample } \\
\text { means }\end{array}$ & $\begin{array}{c}\text { Greater than } \\
\text { LoD* }\end{array}$ & $\begin{array}{l}\text { Range of sample } \\
\text { means }\end{array}$ & $\begin{array}{l}\text { Greater than } \\
\text { LoD* }\end{array}$ & Range of sample means \\
\hline & & cells $\mathrm{mL}^{-1}$ & & pM of ATP & & $\mathrm{EU} \mathrm{mL}^{-1}$ of LPS \\
\hline Debris-rich ice & 6 of 6 & 34 300-1 150000 & 3 of 12 & $0.196-157$ & 0 of 6 & \\
\hline Clean ice & 6 of 6 & $177-1470$ & 6 of 6 & $0.00958-1.15$ & 1 of 6 & 0.244 \\
\hline Subglacial water & 6 of 6 & $774-3150$ & 6 of 6 & $0.0205-0.900$ & 5 of 6 & $3.03-5.25$ \\
\hline Mixed water & 6 of 6 & $274-714$ & 6 of 6 & $0.195-2.11$ & 3 of 3 & $1.57-2.32$ \\
\hline Snow & 2 of 2 & $96-247$ & 2 of 2 & $0.222-1.62$ & 0 of 2 & \\
\hline Total & \multicolumn{2}{|c|}{26 of $26>$ LoD } & \multicolumn{2}{|c|}{23 of $32>$ LoD } & \multicolumn{2}{|c|}{9 of $23>$ LoD } \\
\hline
\end{tabular}

For ATP and LPS the lower limit of detection was considered to be the lowest concentration standard.

* Limit of detection.
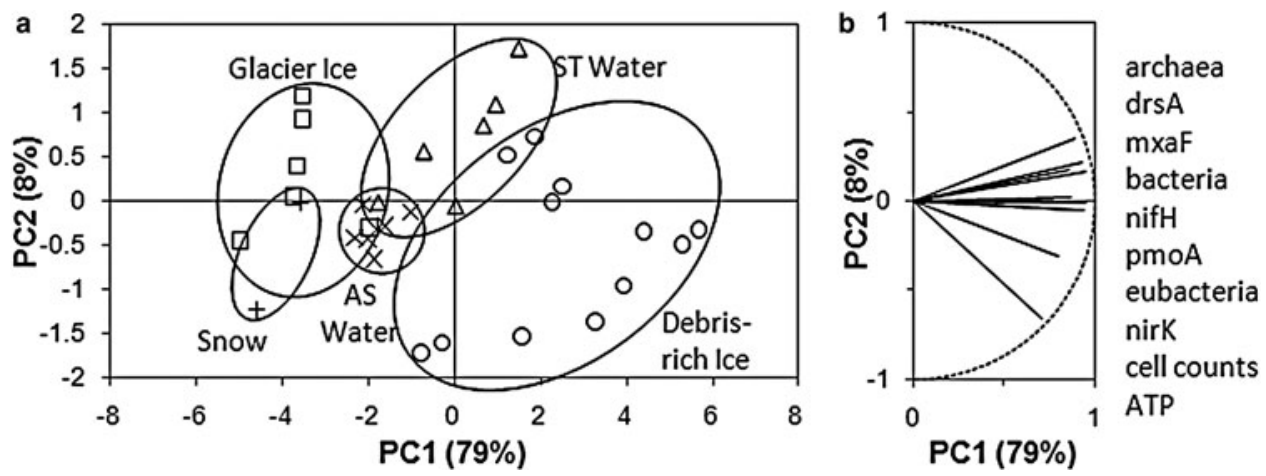

Fig. 1. PCA of the real-time PCR, fluorescence cell counts and ATP bioluminescence data. (a) Projection of the samples (cases). The ovals are placed subjectively to distinguish among the different sample types. (b) Projection of the biomarkers (variables) on the PCA plot.

datasets, PCA can be used for effective allocation of resources, and in particular of staff time and reagents. PCA can be used to identify any techniques that have minimal contribution to variation among samples, as they plot near the origin on a load plot. Figure $1 \mathrm{~b}$ shows that all the techniques contribute significantly to variation among samples; however some of the realtime PCR targets cluster in groups with similar contributions to PC1 and PC2. Therefore, during further sample collection not all analyses may be required. For example one of dsrA, mxaF and bacteria primers could be selected, saving on both time and reagents.

\subsection{Further developments}

The instruments used in this study, or similar instruments, could be used for multiple assays. Modifications may be required to protocols and extraction techniques, or the same instrument could be compatible as the endpoint of an entirely different technique. Modifications to reagents and protocols could potentially be made to detect RNA using thermal cyclers. Alternative extraction kits and more stringent contamination controls should be investigated; RNases are ubiquitous and can readily degrade RNA if samples are not appropriately handled. After each real-time PCR run, melt curves were completed to ensure amplification of the correct size DNA fragment. High resolution melt curves have been used to show changes in community structure (Hjelmsø and others, 2014), however this type of analysis requires a more precise instrument than the thermal cycler transported to Engabreen. More recently, systems such as the LightCycler $^{\circledR} \quad$ Nano (Roche Diagnostics Ltd., Switzerland) and MyGo Pro (IT-IS International Ltd, UK), combine low mass and power requirements for field portability and, according to the manufacturers, have the precision required for high resolution melt analysis. The fluorescence microscope used in Engabreen has interchangeable filters so could be used with alternative excitation and emission wavelengths. Chlorophyll fluorescence can be used to enumerate microalgae and cyanobacteria, and has been applied to microbial communities in subglacial sediments (Kaštovská and others, 2007). Although the fluorimeter transported to Engabreen was limited to two detection channels (with different excitation/emission maximum), these wavelengths are common to several fluorophores and could potentially be used for the endpoint for an entirely different assay. The fluorimeter is compatible with the detection of an enzyme activity assay using the fluorescence of 4-methylumbelliferone (Marx and others, 2001). Enzyme activity is measured by the cleavage of a fluorophore conjugated to a substrate of interest, for example a phosphate conjugate could be used to measure phosphatase activity. The techniques and technology used in this work provide an example of the type of analysis that can be conducted in the field, but many more are possible.

In-field analysis is clearly relevant if little is known about the site. If applied to longer field campaigns, multiple rounds of multiple techniques can be completed in a single campaign, and can quickly build-up a level of knowledge concerning a site that would be impossible if results were not available until after the field campaign was complete. 
In-field analysis could be applicable to previously studied sites to rapidly address new questions that emerge and could still benefit from multiple cycles in a single campaign, for example to interactively track a parameter by being able to select appropriate temporal or spatial sample intervals. Information such as volume required for analysis and verification of sampling strategies and sample processing protocols can be ascertained from early rounds and applied to subsequent analyses.

Using multiple techniques in the field is a promising approach to field analysis. However, its widespread application is currently limited; mostly by sample processing and technology. Sample processing can concentrate and extract the target, or remove potential inhibitors, all of which have to be possible in the field. When addressing the latter two issues, the sample type can dramatically change the effectiveness of biomarker extraction. Multiple commercially available extraction techniques are available for real-time PCR, which was adequate to address the extraction and inhibitor issues in the samples from Engabreen. A simple filtering technique was added to concentrate samples. For less established techniques, insufficient or unsuitable sample processing can be a significant hindrance to biomarker detection, as was suspected in the debris-rich ice samples for ATP bioluminescence and rFC assay. Regarding available technology, the low level of automation of the field deployable instrumentation used here means that field analysis is generally more time consuming than using larger, automated instrumentation. The technology that is currently available limits the variety of techniques that can be performed in the field. However, the demand for small footprint, low power consumption, rugged instruments has increased their availability. The primary focus for applications of these instruments include medical and defence industries as greater funding is available to develop such instruments, for example R.A.P.I.D. ${ }^{\circledR}$ BioDetection System (Idaho Technology Inc., UT, USA); a PCR based instrument for frontline detection of biothreat agents. It is, therefore, anticipated that as such technology and protocols are developed in other areas, these can be transferred and adapted by the geomicrobiology community to complement and enhance the work described here.

\section{CONCLUSION}

Multiple microbial detection and characterization techniques have been applied in-field for the first time in an icy environment. Glacial and glacially-related samples were collected from Engabreen in Northern Norway and analyzed with real-time PCR, fluorescence cell counts, ATP bioluminescence and rFC assay (to detect LPS). The analyses of the samples with multiple techniques resulted in biomarker levels and distributions as expected, i.e. low in glacial ice and higher in debris-rich ice. This demonstrates that it is possible to apply a multi-technique approach to assess subglacial microbial populations in the field. This study shows strong potential for use of these methods in more remote and challenging glacial environments where real time data has the potential to inform time-limited sampling opportunities. An example is the penetration and sampling of Antarctic subglacial lakes (Siegert and others, 2007), where sampling is restricted to a short time window and a small number of samples.
It is recommended that further demonstration of this approach is pursued with the relatively benign in-field environment of the Svartisen Subglacial Laboratory to be replaced with a physically and logistically more challenging field environment. Furthermore, the proposed benefits to be gained from in-field refinement of sampling strategies, multiple rounds of analysis and intelligence-led sampling in a single field campaign should be demonstrated in further studies.

\section{ACKNOWLEDGEMENTS}

This work was funded by EPSRC grant number EP/D057620/1. We thank the members of the November 2008 and March 2009 Engabreen field campaigns, in particular Sabine Leggner and Jon Endre Hausberg, Dr. Fred Coulon for advice on the optimization of real-time PCR conditions and Simon Waters for advice on statistical analyses. We thank Bio-Rad Laboratories Ltd for the loan of equipment and donation of reagents leading up to the November 2008 field campaign. Enquiries for access to the data referred to in this article should be directed to d.cullen@cranfield.ac.uk. Finally, we thank the reviewers for helpful comments.

\section{REFERENCES}

Anesio AM and Laybourn-Parry J (2012) Glaciers and ice sheets as a biome. Trends Ecol. Evol., 27, 219-225 (doi: 10.1016/j. tree.2011.09.012)

Aycicek H, Oguz U and Karci K (2006) Comparison of results of ATP bioluminescence and traditional hygiene swabbing methods for the determination of surface cleanliness at a hospital kitchen. Int. J. Hyg. Envir. Heal., 209(2), 203-206 (doi: 10.1016/j. ijheh.2005.09.007)

Baker G, Smith JJ and Cowan DA (2003) Review and re-analysis of domain-specific $16 \mathrm{~S}$ primers. J. Microbiol. Meth., 55(3), 541555 (doi: 10.1016/j.mimet.2003.08.009)

Barnett MJ (2010) Implementation of in-field life detection and characterisation techniques in icy environments. (PhD thesis, Cranfield University)

Barnett MJ, Pearce DA and Cullen DC (2012a) Advances in the infield detection of microorganisms in ice. Adv. Appl. Microbiol., 81, 133-167 (doi: 10.1016/B978-0-12-394382-8.00004-6)

Barnett MJ, Wadham JL, Jackson M and Cullen DC (2012b) In-field implementation of a recombinant factor $C$ assay for the detection of lipopolysaccharide as a biomarker of extant life within glacial environments. Biosensors, 2(1), 83-100 (doi: 10.3390/ bios2010083)

Boyd E and 8 others (2011) Diversity, abundance, and potential activity of nitrifying and nitrate-reducing microbial assemblages in a subglacial ecosystem. Appl. Environ. Microbiol., 77(14), 47784787 (doi: 10.1128/AEM.00376-11)

Braker G, Fesefeldt A and Witzel K-P (1998) Development of PCR primer systems for amplification of nitrite reductase genes (nirK and nirS) to detect denitrifying bacteria in environmental samples. Appl. Environ. Microbiol., 64(10), 3769-3775 (doi: 0099-2240/98/\$04.0010)

Cameron KA, Hodson AJ and Osborn AM (2012) Carbon and nitrogen biogeochemical cycling potentials of supraglacial cryoconite communities. Polar Biol., 35, 1375-1393 (doi: 10.1007/s00300012-1178-3)

Christner BC, Skidmore ML, Priscu JC, Tranter M and Foreman CM (2008) Bacteria in subglacial environments. In Margesin R, Schinner F, Marx J-C and Gerday C eds. Psychrophiles: from biodiversity to biotechnology. Springer Berlin Heidelberg, Berlin, Heidelberg. chpt 4, 51-71 
Christner BC, Mosley-Thompson E, Thompson LG and Reeve JN (2001) Isolation of bacteria and 16S rDNA from Lake Vostok accretion ice. Environ. Microbiol., 3(9), 570-577

Costello AM and Lidstrom ME (1999) Molecular characterization of functional and phylogenetic genes from natural populations of methanotrophs in lake sediments. Appl. Environ. Microbiol., 65 (11), 5066-5074 (doi: 0099-2240/99/\$04.0010)

Cowan DA, Russell NJ, Mamais A and Sheppard DM (2002) Antarctic Dry Valley mineral soils contain unexpectedly high levels of microbial biomass. Extremophiles, 6(5), 431-436 (doi: 10.1007/s00792-002-0276-5)

Ding JL and Ho B (2001) A new era in pyrogen testing. Trends Biotechnol., 19(8), 277-281 (doi: 10.1016/S0167-7799(01) 01694-8)

Fairbanks BC and 5 others (1984) Limitations of ATP estimates of microbial biomass. Soil Biol. Biochem., 16(6), 549-558 (doi: 10.1016/0038-0717(84)90071-3)

Foght J and 6 others (2004) Culturable bacteria in subglacial sediments and ice from two southern hemisphere glaciers. Microbial Ecol., 47(4), 329-340 (doi: 10.1007/s00248-0031036-5)

Gaidos E and 7 others (2004) A viable microbial community in a subglacial volcanic crater lake, Iceland. Astrobiology, 4(3), 327-344

Geets J and 7 others (2007) Real-time PCR assay for the simultaneous quantification of nitrifying and denitrifying bacteria in activated sludge. Appl. Microbiol. Biotechnol., 75(1), 211-221 (doi: 10.1007/s00253-006-0805-8)

Hjelmsø MH and 5 others (2014) High-resolution melt analysis for rapid comparison of bacterial community compositions. Appl. Environ. Microbiol., $\mathbf{8 0}(12), \quad 3568-3575$ (doi: 10.1128/ AEM.03923-13)

Hodson A and 10 others (2007) A glacier respires: quantifying the distribution and respiration $\mathrm{CO}_{2}$ flux of cryoconite across an entire Arctic supraglacial ecosystem. J. Geophys, Res., 112 (G4), art. no. G04S36 (doi: 10.1128/AEM.03923-13)

Hodson A and 7 others (2008) Glacial ecosystems. Ecol. Monogr., 78(1), 41-67

Inagaki F and 8 others (2004) Characterization of C1-metabolizing prokaryotic communities in methane seep habitats at the Kuroshima Knoll, Southern Ryukyu Arc, by analyzing pmoA, mmoX, mxaF, mcrA, and 16S rRNA genes. Appl. Environ. Microbiol., 70(12), 7445-7455 (doi: 10.1128/AEM.70.12. 7445-7455.2004)

Irvine-Fynn TDL, Edwards A (2014) A frozen asset: the potential of flow cytometry in constraining the glacial biome. Cytometry $A$, 85(1), 3-7 (doi: 10.1002/cyto.a.22411)

Jenkinson DS and Oades JM (1979) A method for measuring adenosine triphosphate in soil. Soil Biol. Biochem., 11(2), 193-199

Kandeler E, Deiglmayr K, Tscherko D, Bru D and Philippot L (2006) Abundance of narG, nirS, nirK, and nosZ genes of denitrifying bacteria during primary successions of a glacier foreland. Appl. Environ. Microbiol., 72(9), 5957-5962 (doi: 10.1128/AEM. 00439-06)

Karl DM and 5 others (1999) Microorganisms in the accreted ice of Lake Vostok, Antarctica. Science, 286(5447), 2144-2147 (doi: 10.1126/science.286.5447.2144)

Karr EA and 5 others (2005) Diversity and distribution of sulfate-reducing bacteria in permanently frozen Lake Fryxell, McMurdo Dry Valleys, Antarctica. Appl. Environ. Microbiol., 71(10), 6353-6359 (doi: 10.1128/AEM.71.10.6353-6359.2005)

Kaštovská K and 5 others (2007) Microbial community structure and ecology of subglacial sediments in two polythermal Svalbard glaciers characterized by epifluorescence microscopy and PLFA. Polar Biol., 30(3), 277-287 (doi: 10.1007/s00300006-0181-y)

Klaschik S and 5 others (2002) Real-time PCR for detection and differentiation of gram-positive and gram-negative bacteria. J. Clin. Microbiol., 40(11), 4304-4307 (doi: 10.1128/JCM.40.11.43044307.2002)
Kolb S, Knief C, Stubner S and Conrad R (2003) Quantitative detection of methanotrophs in soil by novel pmoA-targeted real-time PCR assays. Appl. Environ. Microbiol., 69(5), 2423-2429 (doi: 10.1128/AEM.69.5.2423-2429.2003)

Kondo R, Nedwell DB, Purdy KJ and Silva SQ (2004) Detection and enumeration of sulphate-reducing bacteria in estuarine sediments by competitive PCR. Geomicrobiol. J., 21(3), 145-157 (doi: 10.1080/01490450490275307)

La Ferla R, Lo Giudice A and Maimone G (2004) Morphology and LPS content for the estimation of marine bacterioplankton biomass in the lonian Sea. Sci. Mar., 68(1), 23-31

Leloup J and 5 others (2007) Diversity and abundance of sulfate-reducing microorganisms in the sulfate and methane zones of a marine sediment, Black Sea. Environ. Microbiol., 9(1), 131-142 (doi: 10.1111/j.1462-2920.2006.01122.x)

Mader HM, Pettitt ME, Wadham JL, Wolff EW and Parkes RJ (2006) Subsurface ice as a microbial habitat. Geology, 34(3), 169-172 (doi: 10.1130/G22096.1)

Manerkar M, Seena S and Bärlocher F (2008) Q-RT-PCR for assessing archaea, bacteria, and fungi during leaf decomposition in a stream. Microbial Ecol., 56(3), 467-473 (doi: 10.1007/ s00248-008-9365-z)

Marx MC, Wood M and Jarvis SC (2001) A microplate fluorimetric assay for the study of enzyme diversity in soils. Soil Biol. Biochem., 33, 1633-1640 (doi: 10.1016/S0038-0717(01)00079-7)

McDonald IR and Murrell JC (1997) The methanol dehydrogenase structural gene mxaF and its use as a functional gene probe for methanotrophs and methylotrophs. Appl. Environ. Microbiol., 63(8), 3218-3224

Mikucki JA and 8 others (2009) A contemporary microbially maintained subglacial ferrous "ocean". Science, 324(5925), 397400 (doi: 10.1126/science.1167350)

Mitchell AC, Lafrenière MJ, Skidmore ML and Boyd ES (2013) Influence of bedrock mineral composition on microbial diversity in a subglacial environment. Geology, 41(8), 855-858 (doi: 10.1130/G34194.1)

Nadeau JL and 5 others (2008) Fluorescence microscopy as a tool for in situ life detection. Astrobiology, 8(4), 859-874 (doi: 10.1089/ ast.2007.0043)

Ogilvie L, Hirsch P and Johnston A (2008) Bacterial diversity of the broadbalk 'classical' winter wheat experiment in relation to longterm fertilizer inputs. Microbial Ecol., 56(3), 525-537 (doi: 10.1007/s00248-008-9372-0)

Olson JB, Steppe TF, Litaker RW and Paerl HW (1998) N2-fixing microbial consortia associated with the ice over of Lake Bonney, Antarctica. Microbial Ecol., 36(3), 231-238

Pacheco-Oliver M, McDonald IR, Groleau D, Murrell JC and Miguez CB (2002) Detection of methanotrophs with highly divergent pmoA genes from Arctic soils. FEMS Microbiol. Lett., 209, 313-319 (doi: 10.1111/j.1574-6968.2002.tb11150.x)

Rösch C, Mergel A and Bothe H (2002) Biodiversity of denitrifying and dinitrogen-fixing bacteria in an acid forest soil. Appl. Environ. Microbiol., 68(8), 3818-3829 (doi: 10.1128/AEM.68. 8.3818-3829.2002)

Sala MM and 5 others (2005) Functional diversity of bacterioplankton assemblages in western Antarctic seawaters during late spring. Mar. Ecol.-Prog. Ser., 292, 13-21 (doi: 10.3354/meps292013)

Schaumberger S, Ladinig A, Reisinger $N$, Ritzmann $M$ and Schatzmayr G (2014) Evaluation of the endotoxin binding efficiency of clay minerals using the Limulus Amebocyte lysate test: an in vitro study. AMB Express, 4(1), 1-9 (doi: 10.1186/ 2191-0855-4-1)

Segawa T, Miyamoto K, Ushida K, Agata K, Okada N and Kohshima S (2005) Seasonal change in bacterial flora and biomass in mountain snow from the Tateyama Mountains, Japan, analyzed by $16 \mathrm{~S}$ rRNA gene sequencing and real-time PCR. Appl. Environ. Microbiol., 71(1), 123-130 (doi: 10.1128/ AEM.71.1.123-130.2005)

Sharp $M$ and 5 others (1999) Widespread bacterial populations at glacier beds and their relationship to rock weathering and 
carbon cycling. Geology, 27(2), 107-110 (doi: 10.1130/00917613(1999)027<0107:WBPAGB > 2.3.CO;2)

Siegert MJ and 30 others (2007) Exploration of Ellsworth Subglacial Lake: a concept paper on the development, organisation and execution of an experiment to explore, measure and sample the environment of a West Antarctic subglacial lake: The Lake Ellsworth Consortium. Rev. Envir. Sci. Bio/Technol., 6(1-3), 161-179 (doi: 10.1007/s11157-006-9109-9)

Simon C, Wiezer A, Strittmatter AW and Daniel R (2009) Phylogenetic diversity and metabolic potential revealed in ice metagenome. Appl. Environ. Microbiol., 75(23), 7519-7526 (doi: 10.1128/AEM.00946-09)

Sjöling S and Cowan DA (2003) High 16S rDNA bacterial diversity in glacial meltwater lake sediment, Bratina Island, Antarctica. Extremophiles, 7(4), 275-282 (doi: 10.1007/s00792003-0321-z)

Skidmore M, Anderson SP, Sharp M, Foght J and Lanoil BD (2005) Comparison of microbial community compositions of two subglacial environments reveals a possible role for microbes in chemical weathering processes. Appl. Environ. Microbiol., 71(11), 6986-6997 (doi: 10.1128/AEM.71.11.69866997.2005)

Skidmore ML, Foght JM and Sharp MJ (2000) Microbial life beneath a High Arctic glacier. Appl. Environ. Microbiol., 66(8), 32143220 (doi: 10.1128/AEM.66.8.3214-3220.2000)

Stibal M and 11 others (2012) Methanogenic potential of Arctic and Antarctic subglacial environments with contrasting organic carbon sources. Global Change Biol., 18(11), 3332-3345 (doi: 10.1111/j.1365-2486.2012.02763.x)
Stibal M and 10 others (2015) Microbial abundance in surface ice on the Greenland Ice Sheet. Front. Microbiol., 6, 225 (doi: 10.3389/ fmicb.2015.00225)

Tabachnick BG and Fidell LS (2007) Using multivariate statistics, 5th edn. Pearson International, UK

Wadham JL, Bottrell S, Tranter M and Raiswell R (2004) Stable isotope evidence for microbial sulphate reduction at the bed of a polythermal high Arctic glacier. Earth Planet. Sci. Lett., 219(3-4), 341-355 (doi: 10.1016/S0012-821X(03) 00683-6)

Wadham JL and 6 others (2013) The potential role of the Antarctic Ice Sheet in global biogeochemical cycles. Earth Env. Sci. T. R. Soc., 104, 1-13 (doi: 10.1017/S1755691013000108)

Wartiainen I, Hestnes AG and Svenning MM (2003) Methanotrophic diversity in high arctic wetlands on the islands of Svalbard (Norway) - denaturing gradient gel electrophoresis analysis of soil DNA and enrichment cultures. Can. J. Microbiol., 49(10), 602-612 (doi: 10.1139/w03-080)

Yu Y, Lee C and Hwang S (2005) Analysis of community structures in anaerobic processes using a quantitative real-time PCR method. Water Sci. Technol., 52(1-2), 85-91

Zarsky JD and 7 others (2013) Large cryoconite aggregates on a Svalbard glacier support a diverse microbial community including ammonia-oxidizing archaea. Environ. Res. Lett., 8, 035044 (doi: 10.1088/1748-9326/8/3/035044)

Zhang XF, Yao TD, Tian LD, Xu SJ and An LZ (2008) Phylogenetic and physiological diversity of bacteria isolated from Puruogangri ice core. Microbial Ecol., 55, 476-488 (doi: 10.1007/s00248-007-9293-3)

MS received 14 May 2015 and accepted in revised form 26 October 2015; first published online 4 April 2016 